subsidized public sector and a private side that does not receive public funding.

Experiences elsewhere in Latin America are mixed. Uruguay seems to follow developments in countries like Argentina, with a dominant public sector and small niches of competition including graduate education. Nevertheless, private and public institutions are increasingly engaging in a new competitive dynamic as private enrollments grow and the public university gets involved in some privatized endeavors.

\section{Dual Privatization in Georgian Higher Education}

\section{Marie Pachuashvili \\ Marie Pachuashvili is a Ph.D. candidate in political science at Central European University in Budapest, Hungary and a PROPHE affiliate. E- mail:pphpamo1@phd.ceu.hu.}

Tn postcommunist countries, a significant transformation of 1 the higher education landscape has taken place since the collapse of communism - in the form of diminished state involvement in funding, provision, and governance. The extent and shape of the shift varies by country, but all postcommunist countries witness former public monopolies challenged by some form of privatization. There is usually dual privatization: (a) the growth of private institutions and (b) the introduction of tuition fees and increased businesslike behavior at public universities. Georgia has experienced both forms of privatization.

Like many countries in the region, Georgia has almost no history of private higher education. Georgian private institutions first appeared in I991. Yet, by the 1992-I993 academic year I3I such institutions already existed. The collapse of the Georgian economy and decline in state support for public institutions contributed to diminished public-sector enrollments (an apparent parallel to trends in Central Asian and Baltic countries). Several new public institutions opened, but the public sector saw a 20 percent overall decline in the first half of the I990s. This period represented the time frame of private institutions' founding and most intensive growth. The expansion of the comparatively large private sector peaked at 34 percent of total enrollments in 1995-1996.

\section{Public-Sector Privatization}

Since that peak, however, private-sector enrollments have fallen in relative and even in absolute terms. While the first fall is not unusual in the region, the second is. Demand for publicly provided education, by contrast, has increased since I997-I998. Just as the rise in private higher education reduced public enrollments, public-sector reform is now taking a toll on the private higher education sector.
There is one leading element in the public-sector reform: the growing body of self-financed students, which is a striking aspect of privatization within the public sector both within and beyond the region. Authorization for this change came in 1993. By 2002, 43 percent of the public sector's students paid tuition, and the share has risen each year. Student payments represent the major source of income for some public universities. For instance, in 200I-2002, student tuition revenues at Tbilisi State University and the Medical University were, respectively, two and three times higher than funds received from the state.

The dependence of public institutions on student tuition fees has blurred the distinction between the activities and missions of the two sectors in Georgia. In an attempt to attract more fee-paying students, public institutions have tried hard to stay attuned to labor-market fluctuations by providing training in fields like information technology, law, business administration, and foreign languages. Today, most public educational organizations run programs in law and economics. In addition, besides the official Georgian language of instruction, courses are offered in Russian, English, German, Armenian, and Azeri. Such ethnic appeal has been a hallmark of private higher education, often frowned upon by national public institutions. Thus, the new involvement of public universities is a significant development.

\section{According to the 2004 law on higher education, successful candidates receiving the state finan- cial grant can choose from among all accredit- ed institutions, both public and private.}

Additionally, by introducing vouchers for financing higher education, the Georgian government intends to encourage even more marketlike behavior on the part of public institutions and to promote competition between and within the two sectors of higher education. According to the 2004 law on higher education, successful candidates receiving the state financial grant can choose from among all accredited institutions, both public and private. This would further blur publicprivate differences, at least in reference to accredited private institutions. Furthermore, neither public institutions, which long held a monopoly, nor private institutions, which enjoyed a period of rather easy growth during the I990s, would fare well without being competitive-both inter- and (largely) intrasectorally.

\section{CONCLUSION}

In summary, extensive privatization of the previously public higher education system has been taking place in Georgia since 1989. The shift relates to the creation and growth of a distinct private sector as well as to public institutions increasingly supplementing public funding with private resources, mostly through tuition. The Georgian case corresponds in key respects to developments in the region, but it is striking for 
several reasons. One is the absence of a tradition of private higher education. Second is the comparatively large private higher education share of total enrollments. Third is the relatively vigorous privatization of public education financing. Both the second and third developments stimulate striking private-public mixes, dynamics, and competition.

\section{Mexico’s Brain Drain}

\section{Sylvie Didou Aupetit}

Sylvie Didou Aupetit is a researcher at Mexico's Centre for Advanced Research and Studies and is head of UNESCO's Chair on Quality Assurance and Emerging Providers of Tertiary Education. E-mail: didou@) cinvestav.mx.

$\mathrm{T}$ he Mexican press constantly expresses its concerns about brain drain, but, perhaps because its impact has been officially underrated, the matter has so far not appeared on the education research or policy agendas. While brain drain is calculated to involve only 5 percent of the students granted postgraduate studies abroad, that estimate is low-for the following reasons: (I) because it is based on findings from a sample used to evaluate the National Council of Science and Technology (CONACYT) scholarship program over the past 30 years; (2) because it does not incorporate the free movers who have used alternative mobility channels to study abroad; (3) because the mobility of highly qualified personnel includes, other than the academic market, additional fields of endeavor such as, for instance, the productive sector; and (4) because the intention expressed by young Mexican PhD holders to remain in the United States after obtaining their degrees has increased (notoriously) in recent years-almost matching the preference of Argentines and Chileans with US doctorates to remain abroad. Given these factors, the brain drain estimation would vastly surpass 5 percent. However, to reach a reliable approximation of the phenomenon would require mobilizing financial and human resources and organizing joint cooperative programs-to develop linkages between highly skilled Mexican institutions and institutions located in their countries of origin-as well as recognizing the existence of a vexing problem that the public authorities have opted to ignore.

\section{From Conventional Policies to No Policies?}

Paradoxically, while academic circles and antigovernment groups are expressing renewed alarm about the "exodus of talented minds," the policies established ro years ago to combat the trend are coming to an end. In the early I99os, the PACIME Program ("in support of Mexican science"), cofinanced by the World Bank and the Mexican government, was set up in an attempt to repatriate doctoral graduates from abroad and invite interested foreign scientists into the country.
PACIME was a conventional program, aimed at repatriation or medium-term stays, but it also focused on the multipolar flow of highly qualified human resources which was partially substituting the bipolar South-to-North dynamic. Under favorable international circumstances (the collapse of the Soviet bloc, the extended crisis in Cuba, and the difficult return to peace in Central America), the program's success was striking. Not only did it attract a significant number of Mexican and foreign doctoral degree holders, but it also encouraged national state universities desiring to enhance their research capacities to enlist the services of these repatriates and visitors.

The apparent results were not sufficient, and once the PACIME program was terminated, the repatriation and invitation efforts went into decline. Mexico received 299 foreign academics in I994 and only 49 in 2002 . Jaime Parada, director of CONACYT, recently attributed this decline to the lack of a specific budget. His statement probably indicated the end of a policy that, despite its traditionalism, showed immediate and positive results. Will another kind of program take its place? There is nothing to point in that direction, but the situation calls for answers to several questions.

\section{Paradoxically, while academic circles and antigovernment groups are expressing renewed alarm about the "exodus of talented minds," the policies established 10 years ago to combat the trend are coming to an end.}

Does a country with substantial inflows of money from its citizens abroad not also need the academic assistance of its most educated expatriates? Can it be that Mexico lacks the means for utilizing the experience accumulated abroad (inside and outside Latin America) through brain bank or the organization of scientific and productive diasporas? Is it that Mexico can only perceive the brain drain - a term that forms part of the national rhetoric in lieu of a more neutral expression, such as brain circulation - as a form of treason against the motherland, an absolute loss of capacities, or an inevitable consequence of neocolonialism and thus fail to understand the double meaning of both risk and opportunity?

\section{Strategic Challenge}

A country such as Mexico experiences many challenges especially under the present circumstances. Some are well known - the result of asymmetric professional working conditions between Mexico and its main trade partners, the difficulties faced by the national academic market in absorbing young doctoral degree holders, as well as all the country's bureaucratic, credit, and fiscal requirements, which discourage the creation of business enterprises.

However, the significance of some other issues is underestimated, despite their relevance in the context of nonterritorial recruitment dynamics and "circulating elites." Developed 